\title{
BERGADA RAJAMALA SEMANGGI
}

\author{
Tubagus Mulyadi, Slamet \\ Jurusan Tari, Fakultas Seni Pertunjukan \\ Institut Seni Indonesia (ISI) Surakarta \\ Email: tubagus@isi-ska.ac.id \\ Email: slamet67@isi-ska.ac.id
}

\begin{abstract}
Rajamala is a puppet character from Mahabarata story which represents an incarnation of Dewi Loroamis' disease in a form of a small-giant little boy. Rajamala is a symbol of disaster that must be removed from human life. This event inspired Sultan HBX to create a ship Cantik Baito in the form of Rajamala's face in order to get safety trip to Madura through Semanggianchorage at Bengawan Solo River. The Rajamala at Cantik Baito, then, became inspiration for the Semanggi community to create "Bergada Rajamala", an army with Rajamala mask. This creation is related to the anchoragesite in Semanggi. The problem of this study is about how to brand Rajamala as an icon of Semanggi and why it is necessary to make "Bergada Rajamala" in Semanggi parade. This study uses the method of creation through observation, exploration, experimentation, reflection, and formation. The results obtained include the creation of the parade dance or "Bergada" dance that use Rajamala mask costumes that is called "BergadaRajamalaSemanggi."
\end{abstract}

KeyWords: Rajamala, Bergada, Semanggi.

\section{Pendahuluan}

Potensi suatu daerah dapat dilihat dari aspek kesejarahan dan sumber daya manusianya. Pemberdayaan masyarakat khususnya pada potensi daerah perlu dibranding menjadi sebuah identitas daerah. Kelurahan Semanggi yang berada ditepian Bengawan Solo merupakan salah satu daerah lalu lintas sungai di zamannya. Peristiwa yang pernah terjadi di Semanggi sebagai Bandar bersandarnya kapal HB X yang bercanthik Rajamala sehingga peristiwa ini menjadi potensi kesejarahan untuk dijadikan icon Kelurahan Semanggi.

Berdasar potensi kesejarahan ini perlu kiranya digarap sebuah Incon Bergada Rajamala. Bergada atau Barisan sebuah bentuk garap kelompok yang mengangkat Bergada Pasukan Perang Kerajaan Kasunanan Surakarta namun dalam hal ini garapan Bergada Rajamala lebih ditekankan pada segi artistik tokoh Rajamala dengan kostum dan gerak disertai alunan gending dalam bentuk berisan. Bergada Rajamala digarap dengan bentuk gerakan tari berjalan yang tekanannya lebih pada rampak gerak. Disesuaikan dengan karakter Rajamala.

Konsep garap ini merupakan bentuk branding terhadap Kelurahan Semanggi,maka garapan ini diperuntukkan untuk daerah sebagai ekspresi budaya. Mengkaji permasalahan di atas sebagai dasar pembuatan karya maka rumusan masalahnya adalah sebagai berikut.

1. Mengapa perlu digarap Bergada RajamalaSemanggi?

2. Bagaimana bentuk garap Bergada RajamalaSemanggi?

Penelitian ini dapat dikatan berhasil apabila tujuan dalam penelitian ini dapat tercapai. Adapun tujuan dari penelitian ini adalah untuk melestarikan dan mengembangkan budaya Grebeg Semanggi perlu digarap sebuah Bergada 
Rajamala. Penggarapan Bergada Rajamala ini sebagai bentuk referensi garap gerak pada pasukan berbaris.

Pustaka-pustaka tulis yang digunakan sebagai referensi model penelitian artitstik ini, yaitu buku-buku yang membahas tentang topeng adalah tulisan John Emigh, Masked Performance: The Play of Self and Other in Ritual and Theatre (Philadelphia, University of Pensylvania Press: 1996). John Emigh menjelaskan tentang pertunjukan-pertunjukan seremonial yang tidak dilakukan asal-asalan, tetapi dilakukan pada waktu-waktu terjadi krisis dan pembaruan. Pertunjukan cenderung dilakukan untuk menggambarkan pada kejadiankejadian peralihan, di mana keberlangsungan dan perubahan, masa lalu dan masa depan, sedang mencoba mencari keseimbangan, yang sedang berada di ambang batas. Pustaka tentang topeng dan sejarahnya memberi gambaran tentang penelitian ini, terkait dengan penggunaan topeng Rajamala dalam pertunjukan tari Bergada Rajamala Semanggi.

Artikel berjudul "Kyai Rajamala Kapal "Titanic" Raja Solo, dalam artikel ini menceriteriterakan tentang Rajamala berada di museum Radia Pustaka Surakarta, Rajamala itu hanya berwujud kepala dengan ukuran besar sekali. Pada mulanya kepala itu sebagai canthik (hiasan), biasanya ada di haluan dan buritan sebuah perahu. Canthik Perahu Rajamala merupakan hiasan yang dipasang di ujung depan dan belakang perahu atas prakarsa Paku Buwono V saat masih menjadi putra mahkota. Canthik itu dibuat dari kayu jati yang diambil dari Donoloyo, hutan khusus milik Keraton Surakarta.

Dikisahkan pada 19 November 1809, Paku Buwana IV menerima hadiah dari Gubernur Jenderal William Daendels berupa perahu dengan canthik atau hiasan ujung perahu berupa perawan Belanda. Melihat keindahan perahu itu, Paku Buwana IV berkeinginan membuat perahu sejenis untuk dikawinkan dengan perahu tersebut.

Paku Buwana IV lalu meminta putranya
Pangeran Adipati Anom yang kemudian menjadi Paku Buwana V untuk membuat perahu dengan menggunakan kayu jati dari Hutan Donoloyo. Setelah Perahu Kiai Rajamala yang berukuran 58,9 x 6,5 meter selesai dibuat, perahu persembahan Daendels dan Kiai Rajamala segera dinikahkan dengan upacara lengkap sebagaimana biasanya pernikahan seorang laki-laki dan seorang perempuan. Upacara itu dilaksanakan di Kedhung Penganten Bengawan Solo pada 19 Juli 1811.

Kisah yang menyertai penciptaannya berasal dari peristiwa pelamaran Putri Bupati Cakraningrat di Sumenep Madura, oleh Paku Buwana IV. Karena transportasi paling mungkin saat itu lewat perairan dengan memakai perahu, Paku Buwana IV ingin perahu yang dinaikinya memiliki ornamen bagus. Maka dipilihlah ornamen Rajamala. Pemilihan tokoh Rajamala untuk dijadikan canthik atau hiasan didasarkan atas kesaktian tokoh Raden Rajamala yang tak terkalahkan dalam kisah pewayangan.www. brilio.net/news/rajamala-perahu-milik-keraton.

Selanjutnya Tulisasn berjudul "Legenda Canthik Kyai Rajamala Yang Dahulu Mengarungi Bengawan Solo", artikel ini menceriterakan bahwa di dalam museum yang sekarang umurnya lebih dari satu abad itu, tersimpan banyak sekali peninggalan-peninggalan kuno seperti senjatasenjata kuno, wayang-wayang, artefak-artefak kuno, dan naskah-naskah kuno yang jumlahnya tidak kurang dari tiga ribu lembar.

Museum yang didirikan pada tanggal 28 Oktober 1890 (15 Mulud tahun Ehe 1820) dengan nama Paheman Radya Pustaka oleh Kanjeng Raden Adipati Sosrodiningrat IV Ngendraprasta, mempunyai suatu benda yang menarik untuk diteliti lebih dalam. Benda atau barang tersebut adalah sebuah canthik - pajangan yang berada di depan sebuah kapal—yang berbentuk sebuah kepala. Nama dari canthik tersebut adalah Kyai Rajamala. (wawancara KGPH Puger, 18 april 2018). zaen.blog.uns.ac.id/2016/02/20/legendacanthik-kyai-rajamala-yang.

Metode yang digunakan dalam penelitian ini menggunakan metode penelitian artistik yaitu 
sebuah model penelitian riset by praktek. Metode ini bersifat kwalitatif. Maka langkah-langkah yang digunakan tetap menganut pada metode penelitian kualitatif, teknik pengumpulan datanya meliputi, pengamatan, wawancara, dan studi pustaka. Penyelsarasan metode kualitatif dengan metode artistik yang dikenal dengan metode penciptaan. Meliputi langkah-langkah sebagai berikut, yaitu:

\section{Pengamatan}

a. Pengamatan

Pengamatan merupakan metode pengamatan yang dilakukan pada tahap awal penelitian yaitu dengan mengamati icon Rajamala yang berada di Museum Radia Pustaka Surakarta yang ada di aktifitas masyarakat terhadap unsur budaya kelurahan Semanggi terhadap bentuk tari Golek. Dari hasil amatan ini didapat suatu data tentang bentuk tari Golek, teknik-teknik gerak maupun bentuk pertunjukannya. Data tersebut kemudian diolah menjadi sebuah bentuk garap tari Bergada Rajamala.

b. Eksplorasi

Eksplorasi merupakan cara mencari kemungkinan-kemungkinan berdasar data observasi kedalam sebuah bentuk atau format pertunjukan tari Bergada Rajamala. Data amatan maupun data pustaka sebagai dasar pencarian kemungkinan-kemungkinan garap bentuk tari Bergada Rajamala yang kemudian diformat dalam bentuk karya tari. Hal ini dapat berubah karena perlu adanya eksperimen.

c. Eksperimen

Eksperimen merupakan metode keberlanjutan dari eksplorasi. Hal ini dilakukan sebagai tahap percobaan dari kemungkinankemungkinan pencarian model yang kemudian percobaan itu didapat suatu teknik, pola garap, dan model yang tepat untuk dilakukan perenungan terhadap data yang didapat.

\section{d. Perenungan}

Perenungan merupakan metode sebagai sebuah bentuk telaah kembali terhadap eksplorasi dan eksperimen sebelum penetapan suatu bentuk model pertunjukan barongan panggung dengan demikian perenungan memerlukan beberapa pertimbangan terhadap prototife yang dihasilkan. Maka perlu diperhatikan kondisi masyarakat, model pertunjukan, dan pengguna. Dengan kata lain bagaimana model itu dibuat, dipergunakan, dan dipublikasikan (made used and profesition-publication).

e. Pembentukan

Metode ini merupakan tahap akhir sebelum disosialisasikan atau dilatihkan. Pembentukan dilakukan setelah memandang dari eksperimen atau percobaan serta perenungan dipandang telah mencapai tujuan yang diinginkan baru menetapkan bentuk-bentuk mulai dari motif gerak, tata busana, musik tari, dan pola ceritera yang telah dianggap sesuai dengan tujuan.

f. Pelatihan

Pelatihan merupakan tahap penentu sebelum pelaksanaan karnaval Bergada Rajamala dilakukan dan pelatihan ini dimaksudkan bukan sekedar akhir dari suatu pertunjukan melainkan sebagai suatu sosialisasi terhadap pertunjukan karnaval tersebut.

\section{PEMBAHASAN}

Tari Bergada Rajamala pertama kali dipentaskan pada acara Grebeg Semanggi pada hari minggu, 22 Juli 2018. Pada pukul 06.00 - sampai selesai, para penari sudah melakukan persiapan. Persiapan yang dilakukan sebelum acara atau pementasan berlangsung diadakan beberapa tahapan yaitu antara lain; 1) penyusunan konsep garap; 2) proses penyusunan gerak tari; 3) proses penyusunan iringan; 4) latihan tempuk gending; dan 5) latihan terjadwal untuk pentas. Persiapan tersebut dilakukan terhitung selama 3 bulan 2 minggu dimulai pada bulan April sampai pada pertengahan bulan Juli tahun 2018.

\section{Penyusunan konsep Garap}


Tahap awal yang dilakukan dalam proses penciptaan tari Bergada Rajamala yaitu proses penyusunan konsep garap. Pada tahap pertama ini peneliti melakukan pengamatan atau observasi terlebih dahulu terhadap ikon Rajamala yang berada di Museum Radya Pustaka Surakarta dan aktifitas masyarakatterhadap unsur budaya kelurahan Semanggi danCanthik Baita Rajamala. Dari hasil amatan ini didapat suatu data tentang bentuk Rajamala dan Folklor masyarakat Semanggi tentang bandar yang ada di aliran sungai Bengawan Solo.

Penentuan konsep garap tari Bergada Rajamala ditemukan pada tahap ini. Konsep ini ditemukan berdasarkan amatan yang dilakukan peneliti. Penentuan konsep garap ini juga melibatkan masyarakat, seniman sekitar, serta tokoh masyarakat. Konsep garap yang ditemukan disesuaikan dengan keadaan masyarakat beserta kondisi lingkungan sosialnya, sehingga konsep yang disampaikan dapat diterima oleh masyarakat sekitar sekaligus sebagai masayarakat pemilik.

Konsep Rajamala diambil untuk menamakan garap bentuk tari yang bersifat Bergada atau barisan yang menggunakan topeng Rajamala. Konsep ini dipakai dasar dalam garap bentuk barisan atau Bergada denga gerak berjalan. Penggunaan topeng Rajamala dimaksudkan sebagai pasukan Rajamala yaitu diartikan atau dimaknai sebagai penolak bala. Konsep Rajamala sebagaimana tujuan dari kelurahan Semanggi untuk membrandhing Rajamala sebagai ikon kelurahan Semanggi. Hal ini dilakukan berdasar fakta kesejarahan di Semanggi yaitu sepanjang aliran Bengawan Solo Semanggi sebagai bandar lalulintas sungai bengawan Solo.

\section{Proses penyusunan gerak tari}

Tahap kedua yang dilakukan peneliti adalah penyusunan gerak tari. Pada proses ini terdapat beberapa langkah yang dilakukan antara lain eksplorasi untuk menentukan gerak-gerak tari yang akan disusun berdasarkan amatan pada observasi dari sebuah aktivitas Bergada
Semanggi mengenai upacara tentang sedekah bumi semanggi di aliran sungai Bengawan Solo. Langkah yang dilakukan setelah eksplorasi yaitu eksperimen.

Eksperimen merupakan metode keberlanjutan dari eksplorasi. Pada lanhgkah ke dua ini merupakan tahapan percobaan atau uji coba hasil dari proses eksplorasi. Eksperimen dikembangkan langsung pada para penari Bergada Rajamala. Uji coba gerak dilakukan untuk menentukan gerak yang paling sesuai berdasarkan konsep garap dan cerita yang sudah ditentukan. Selanjutnya dilakukan langkah perenungan.

Perenungan sebagai sebuah bentuk usaha dari peneliti untuk menelaah kembali proses-proses sebelumnya. Langkah ini dimaksudkan sebagai persiapan sebelum penentuan model garap tari yang benarbenar matang. Dalam proses perenungan melihat semua aspek terutama para penari yang melakukan gerakan-gerakannya. Perenungan ini sekaligus mengamati kembali hasil yang didapatkan berdasar indikator keberhasilan akan mencapai sejauh mana proses penciptaan gerak ini berjalan.

Tahap selanjutnya yang dilakukan adalah proses pembentukan. Tahapan ini merupakan tahap akhir sebelum disosialisasikan lagi kepada para penari beserta segala aspek pendukungnya. Pembentukan dilakukan setelah memandang dari eksperimen atau percobaan serta perenungan dipandang telah mencapai tujuan yang diinginkan baru menetapkan bentuk-bentuk mulai dari motif gerak, tata busana, musik tari, dan properti yang akan digunakan.

\section{Proses penyusunan iringan}

Proses penyusunan iringan juga sama dengan proses penyusunan gerak tari. Proses yang dimaksud juga melalui tahapan eksplorasi, eksperimen, perenungan, dan terakhir pembentukan dari iringan yang sesuai. Namun yang membedakan yaitu dalam proses penyusunan gerak melibatkan 
penari dan koreografer, sedangkan proses penyusunan iringan melibatkan pemusik dan komposer. Dalam penyusunan iringan harus disesuaikan dengan konsep garap gerak tari Bergada Rajamala. Proses penggabungan atau sinkronisasi akan dilakukan pada tahapan selanjutnya yaitu pada tahap tempuk gending.

4. Latihan tempuk gending

Latihan tempuk gending merupakan proses penggabungan konsep dari koreografer dan komposer yang difokuskan pada para penari dan pemusik. Pada latihan tempuk gending dilakukan beberapa kali sebelum latihan terjadwal untuk pentas. Sering kali terjadi perubahan gerak maupun iringan. Hal ini untuk saling menyesuaikan dari penari maupun pemusik agar didapat rasa yang sesuai harapan dari peneliti. Latihan tempuk gending dilakukan juga untuk menyelaraskan antara rasa gerak dan rasa musik yang dihasilkan.

5. Latihan terjadwal untuk pentas

Latihan terjadwal yang dilakukan untuk pentas dilakukan selama dua puluh (20) kali yang dimulai dari penyusunan gerak tari dan penyusunan iringan hingga proses latihan tempuk gending. Masing-masing latihan terbagi menjadi sebagai berikut.

\section{Deskripsi Sajian Tari Bergada Rajamala}

Tari Bergada Rajamala disajikan di arak-arakan dan panggung berbentuk arena dalam Grebeg Semanggi. Pada awal sajian penari memasuki panggung diawali dengan penari Bujangganong, kemudian penari Bergada Rajamala memasuki panggung dengan lumaksana. Kemudian dilanjutkan beberapa sekaran-sekaranberjalan lembehan, berjalan samping kanan samping kiri, lampah tiga, sarukan junjung kaki kanan sarukan junjung kaki kiri, berjalan gejug jinjit, berjalan ndangak ndingkluk.Pertunjukan diakhiri penari keluar panggung dengan lumaksana lalu diikuti penari Bujangganong keluar panggung.

\section{Elemen-elemen Pertunjukan Tari Bergada Rajamala}

Elemen-elemen pertunjukan tari Bergada Rajamal memiliki cerita yang membingkai pertunjukan tersebut. adapun elemen-elemen pertunjukannya meliputi: 1) gerak tari; 2) musiktari; 3) rias busana; dan 4) tempat penampilan.

\section{Gerak Tari}

Gerak yang digunakan pada tari Bergada Rajamala difokuskan ke gerak kaki dikarenakan tari ini merupakan tari dengan konteks gerak baris berbaris. Namun demikian juga digunakan gerak kepala untuk gerak variasi dan tangan sebagai gerak selingan.

\section{MusikTari}

\section{Gangsaran 1}

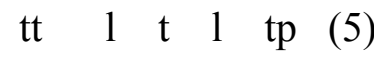

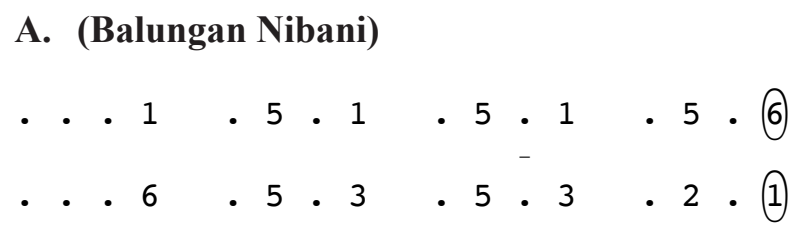

B. (Balungan Mlaku)

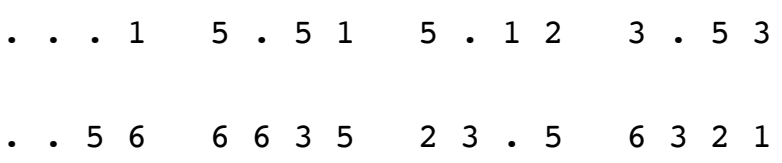

Vokal pada Bagian A

-Rambate Ratahayu

Bersatu melangkah maju

-Untuk nusa dan bangsa

Bergada Sang Rajamala

2. Rias Busana

Rias busana yang digunakan adalah menggunakan kostum dengan topeng Rajamala. 


\section{Arintya Jurnal Penelitian Seni Budaya}

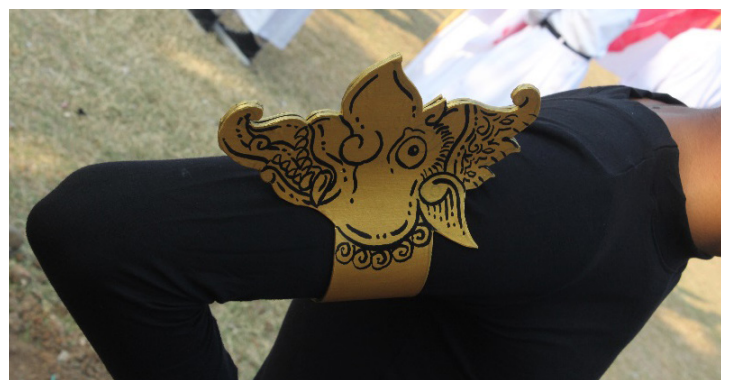

Gambar 1. Klat bahu penari Bergada Rajamala.

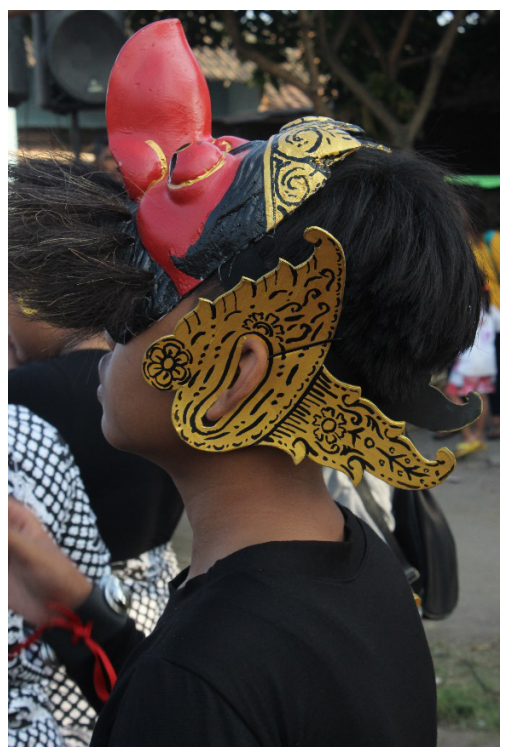

Gambar 2. Sumping penari Bergada Rajamala.

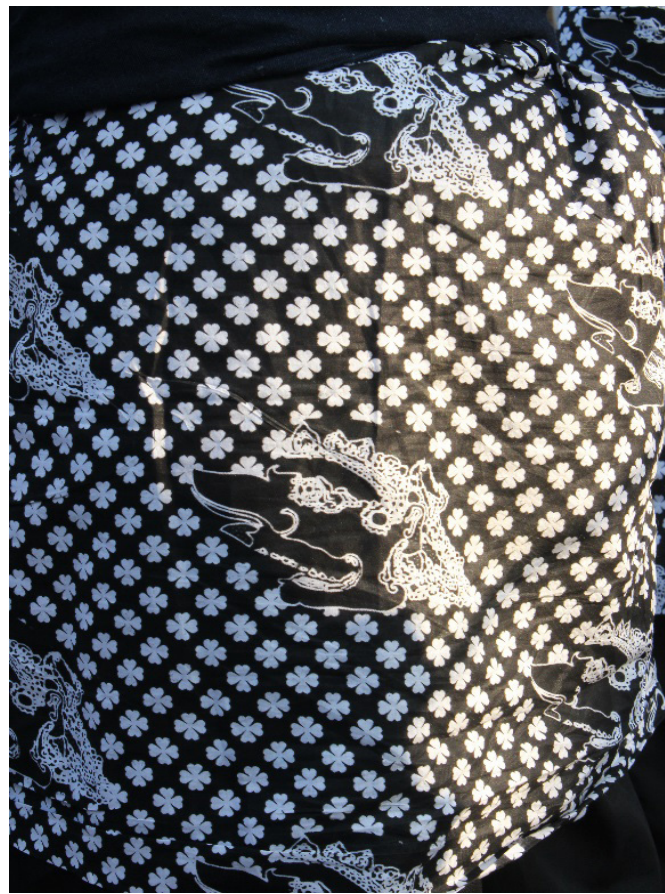

Gambar 3. Kain jari motif Rajamala penari Bergada Rajamala.

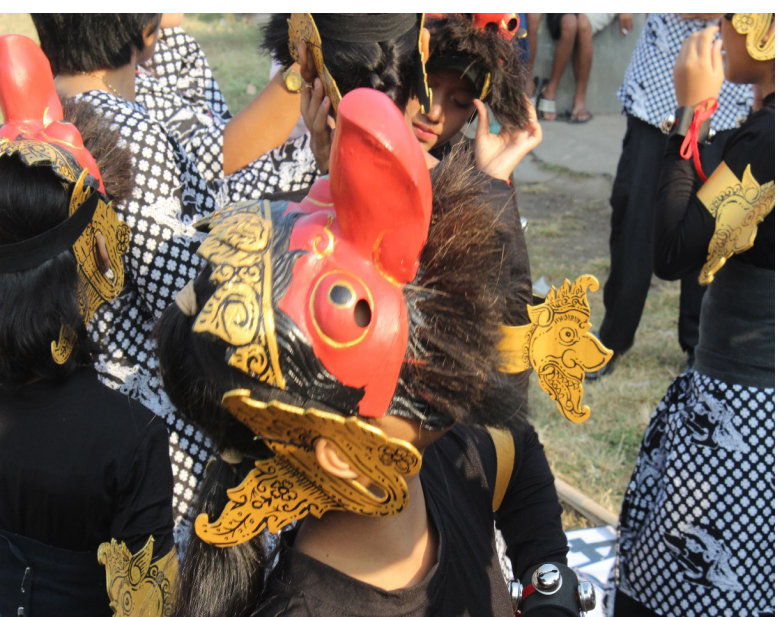

Gambar 4. Topeng Rajamala penari Bergada Rajamala.

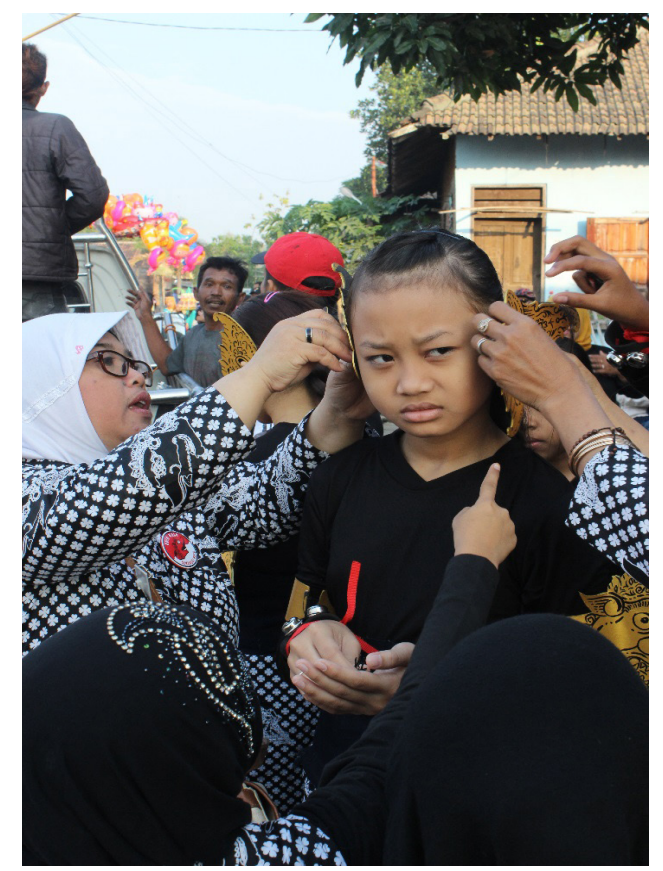

Gambar 5. Rias busana penari Bergada Rajamala.

\section{Tempat Penampilan}

Tempat penampilan tari Bergada Rajamala dilakukan dengan cara arak-arakan dan dengan menggunakan panggung arena. Penampilan dilakukan pada saat Grebeg Semanggi. 


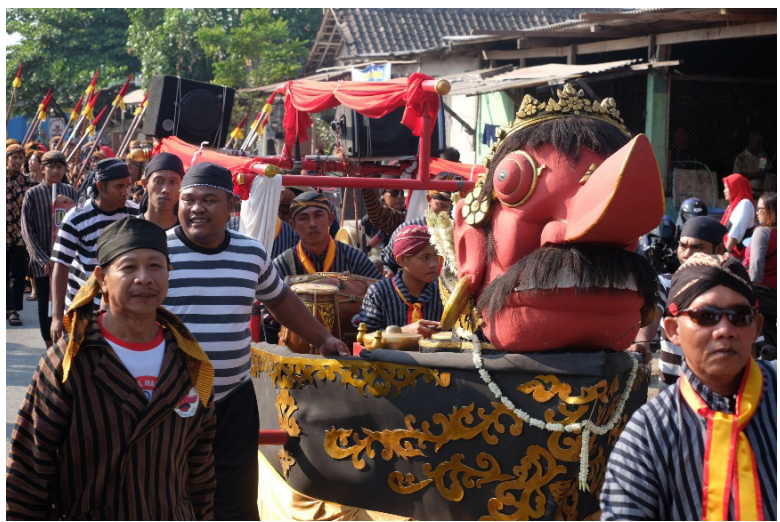

Gambar 6. Perahu Rajamala dan pemusik tari Bergada Rajamala.

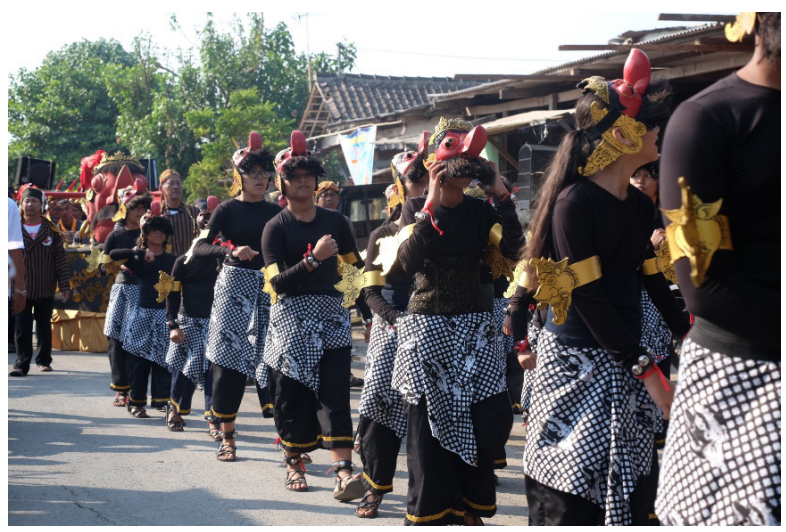

Gambar 7. Tari Bergada Rajamala dalam arakarakan Grebeg Semanggi.

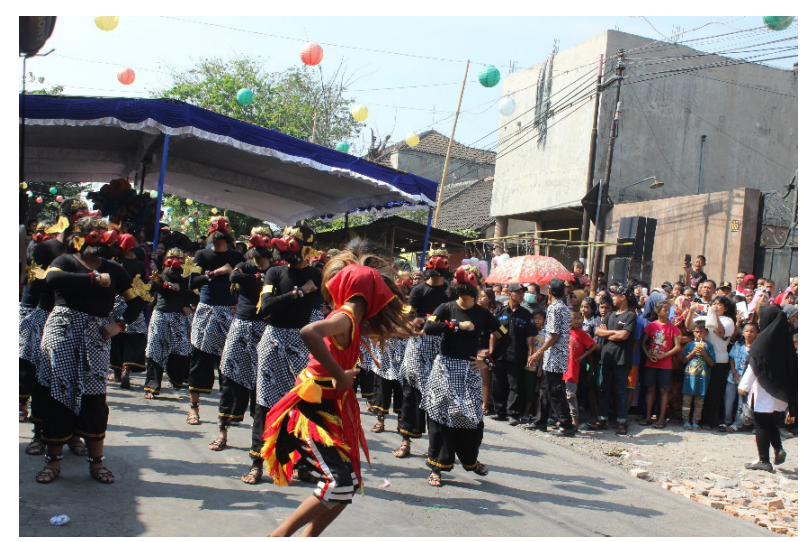

Gambar 8. Penampilan tari Bergada Rajamala.

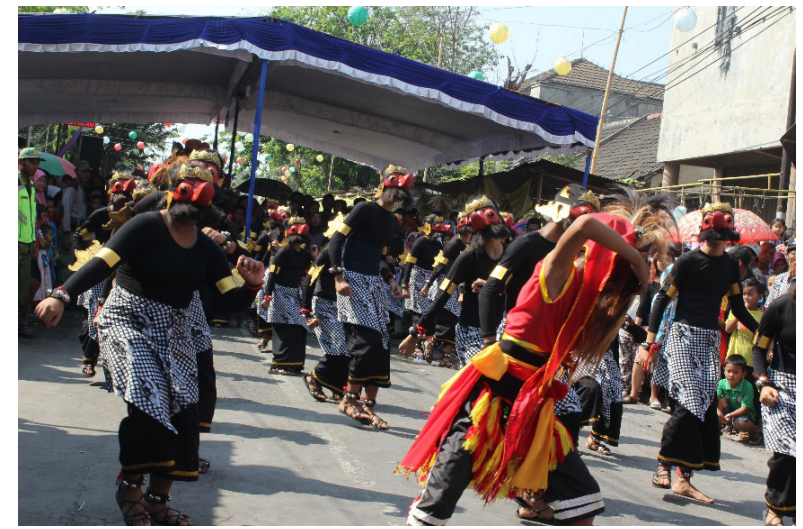

Gambar 9. Penari Bujangganong dan Bergada Rajamala

\section{SIMPULAN}

Penciptaan karya seni tidak hanya mencipta sebuah karya seni, namun melalui proses kekaryaan seni yang di dalamnya terdapat sebuah riset. Kekaryaan seni dapat dikatakan sebagai sebuah bentuk research by practice yang hasil akhirnya berupa karya seni. Tari Bergada Rajamala Semanggi sebuah bentuk karya yang didasari atas riset kesejarahan Kelurahan Semanggi terkait Bandar Semanggi. Perjalanan kesejarahan ini meninggalkan sebuah budaya masyarakat tentang Canthik Rajamala. Melihat latar kesejarahan Semanggi, maka penciptaan BergadaRajamalaSemanggi dapat disimpulkan sebagai berikut.

Pertama, tari Bergada Rajamala Semanggi diciptakan atas kesejarahan Kelurahan Semanggi sebagai branding identitas Kelurahan Semanggi. Kedua, tari Bergada Rajamala Semanggi menggunakan nama berdasarkan Canthik Perahu berupa kepala tokoh pewayangan Rajamala. Selanjutnya disusun gerak-gerak sebagai perwujudan dari kirab barisan Rajamala, yang diberinama Bergada Rajamala. Maka motif gerak tari Bergada Rajamala Semanggi mengambil motif gerak-gerak berjalan. Hal ini terlihat pada motif lumaksana. Kemudian dilanjutkan beberapa sekaran-sekaranberjalan lembehan, berjalan samping kanan samping kiri, lampah tiga, sarukan junjung kaki kanan sarukan junjung kaki kiri, berjalan gejug jinjit, berjalan ndangak ndingkluk. 


\section{tantion}

Daftar Pustaka

Emigh, John, Masked Performance: The Play of Self and Other in Ritual and Theatre, Philadelphia: University of Pensylvania Press, 1996.

Langer, Suzanne K. 1956. Problem of Arts. terj. FX Widaryanto. 2006. Problematika Seni. Bandung: Sunan Ambu Press.

Ricklefs, R.C. Sejarah Indonesia Modern 1200-2004, Jakarta: PT Serambi Ilmu Semesta, 2007.

Sarjiwo. "Cara Pernafasan dan Gerak Torso dalam Tari Golek Menak Yogyakarta" dalam jurnal Imaji UNY Vol. 5, No. 2, Agustus 2007: 196-204.

Schechner, Richard. 2002. Performance studies: an introduction. London: Routledge.

Slamet. Melihat Tari. Surakarta: Citra Sains LPKBN, 2016.

Smith, Jacqueline M. 1985. Dance Composition: a Practical Guide for Teachers. London: A \& Black terj. Ben Suharto. Komposisi Tari :Petunjuk Praktis Bagi Guru.

\section{Narasumber}

KGPH Puger, 65 tahun, pengagengKeraton Surakarta.

J o k o Wiranto, $56 \quad \mathrm{tah} \mathrm{un}$, senimanKelurahanSemanggi.

Sri Rahayu, 47 tahun, guru kesenian SMP 6 Surakarta.

Sularso, 53 tahun, LurahKelurahanSemanggi.

\section{Artikel Internet}

www.brilio.net/news/rajamala-perahu-milikkeraton (diakses pada 22 April 2018 pukul 20.39 WIB).

zaen.blog.uns.ac.id/2016/02/20/legendacanthik-kyai-rajamala-yang (diakses pada 22 April 2018 pukul 21.17 WIB).

\section{Diskografi}

Eri Kisworo, "BergadaRajamalaSemanggi," rekaman Eri Kisworo, Surakarta, 2018. 